\title{
Community Colleges and Economic Mobility
}

\author{
Natalia A. Kolesnikova
}

\begin{abstract}
This paper examines the role of community colleges in the U.S. higher education system and their advantages and shortcomings. In particular, it discusses the population of community college students and economic returns to community college education for various demographic groups. It offers new evidence on the returns to an associate's degree. Furthermore, the paper uses data from the National Survey of College Graduates to compare educational objectives, progress, and labor market outcomes of individuals who start their postsecondary education at community colleges with those who start at four-year colleges. Particular attention is paid to the Federal Reserve's Eighth District, the geographic area served by the Federal Reserve Bank of St. Louis. (JEL I20, I21, J30)
\end{abstract}

Federal Reserve Bank of St. Louis Review, January/February 2010, 92(1), 27-53.

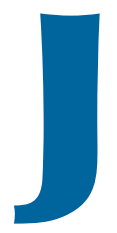

oliet Junior College (Joliet, Illinois), the oldest community college in the nation, was founded in 1901. Since then, community colleges have become increasingly important for the U.S. education and training system. Today, 11.5 million students (6.5 million of whom are studying for college credits) are enrolled in almost 1,200 community colleges, according to the American Association of Community Colleges. Community college students constitute a remarkable 46 percent of all U.S. undergraduates.

The term "junior college" originally referred to any two-year, postsecondary school. Over the last few decades, the term "community college" became more popular to describe public two-year institutions as it better conveys the mission of these colleges to serve their local communities. This distinction was not prevalent before the 1980s and the two terms are still often used interchangeably. However, in 1992 the American
Association of Junior Colleges did change its name to the American Association of Community Colleges.

The original goal of two-year colleges was to prepare students, through an associate's degree (AD) program, to transfer to a four-year college. Over time, the purpose evolved to include workforce training programs, schooling toward certification in areas such as nursing and other professions, and adult continuing education classes. A more recent development is that some community colleges now offer bachelor's degrees in a number of fields.

However, there are big differences across states in how the community college system is used. Rouse (1998) found evidence suggesting that states tend to focus their resources on either a community college or a four-year college system. California has the largest network of the former; 66 percent of the state's current undergraduates attend community colleges. In contrast, only 16

Natalia A. Kolesnikova is an economist at the Federal Reserve Bank in St. Louis. Luke Shimek and Yang Liu provided research assistance. Portions of this paper previously appeared in The Regional Economist (Kolesnikova and Shimek, 2008, and Kolesnikova, 2009a) and as a Federal Reserve Bank of St. Louis Community Development Research Report (Kolesnikova, 2009b).

(C) 2010, The Federal Reserve Bank of St. Louis. The views expressed in this article are those of the author(s) and do not necessarily reflect the views of the Federal Reserve System, the Board of Governors, or the regional Federal Reserve Banks. Articles may be reprinted, reproduced, published, distributed, displayed, and transmitted in their entirety if copyright notice, author name(s), and full citation are included. Abstracts, synopses, and other derivative works may be made only with prior written permission of the Federal Reserve Bank of St. Louis. 


\section{Table 1}

\section{College Enrollment Statistics for the Federal Reserve Eighth District}

\begin{tabular}{lcc} 
Region/State & $\begin{array}{c}\text { Enrollment in community college } \\
\text { (Fall 2005) }\end{array}$ & $\begin{array}{c}\text { Percent of all undergraduates } \\
\text { (Fall 2005) }\end{array}$ \\
\hline United States & $6,184,000$ & 41 \\
Eighth District states & & 37 \\
Arkansas & 47,771 & 51 \\
Illinois & 352,824 & 19 \\
Indiana & 59,969 & 39 \\
Kentucky & 84,669 & 50 \\
Mississippi & 66,298 & \\
Missouri & 86,742 & 28 \\
Tennessee & 74,829 & 31
\end{tabular}

SOURCE: U.S. Department of Education, National Center for Education Statistics.

percent of undergraduates in Nevada and Vermont are enrolled in community colleges. ${ }^{1}$

Among the states within the Federal Reserve System's Eighth District (which consists of all of Arkansas and parts of Missouri, Mississippi, Illinois, Indiana, Tennessee, and Kentucky) Illinois and Mississippi have the largest proportion of undergraduates-about half-in community colleges. Indiana has the lowest percentage-19 percent. Table 1 summarizes enrollment statistics for the Eighth District states.

For many individuals, community colleges represent a unique opportunity to receive a postsecondary education and improve their economic status. Community colleges thus serve as a path to upward economic mobility for a large part of the population. Given the significant role community colleges in U.S. higher education, it is important to have as much information as possible about community college students, their goals, educational choices, and outcomes. This paper concentrates on several of these topics and attempts to present a comprehensive picture of community college education. In particular, it addresses the following questions:

1 These are the 2005 state-level statistics from the National Center for Education (U.S. Department of Education), the latest information available when this paper was written.
- What are the advantages of community colleges compared with traditional fouryear colleges?

- Do students attending community colleges differ from students at traditional four-year colleges?

- What are the economic returns of attending a community college?

- What are the intentions of community college students with regard to their educational objectives?

- Does starting postsecondary education at a community college affect a person's chances of obtaining a bachelor's degree and postgraduate education?

- Do students who attended a community college and received an $\mathrm{AD}$ before obtaining a bachelor's degree have different educational and labor market outcomes than those who did not have an $\mathrm{AD}$ before obtaining a bachelor's degree?

The paper reviews the existing literature on community college education. In addition, it offers new evidence on the returns to attaining an $\mathrm{AD}$ and uses the National Survey of College Graduates (NSCG) to carefully analyze the differences in a variety of educational and economic 
Table 2

Comparisons of College Tuition and Fees for the Federal Reserve Eighth District

\begin{tabular}{lccc} 
& \multicolumn{3}{c}{ Average tuition and required fees (2006-07) } \\
\cline { 2 - 4 } Region/State & $\begin{array}{c}\text { Four-year } \\
\text { public college (in-state) }(\$)\end{array}$ & $\begin{array}{c}\text { Four-year } \\
\text { private college }(\$)\end{array}$ & $\begin{array}{c}\text { Two-year } \\
\text { community college }(\$)\end{array}$ \\
\hline United States & 5,685 & 20,492 & 2,017 \\
Eighth District states & & & 1,890 \\
Arkansas & 4,937 & 13,396 & 2,252 \\
Illinois & 8,038 & 20,181 & 2,713 \\
Indiana & 6,284 & 22,060 & 2,633 \\
Kentucky & 5,821 & 14,739 & 1,709 \\
Mississippi & 4,457 & 12,300 & 2,284 \\
Missouri & 6,320 & 16,539 & 17,576 \\
Tennessee & 5,009 & 1,474
\end{tabular}

SOURCE: U.S. Department of Education, National Center for Education Statistics.

outcomes between individuals who started their postsecondary education at community colleges and those who started at four-year institutions. ${ }^{2}$

\section{ADVANTAGES OF COMMUNITY COLLEGES}

Compared with a traditional four-year college, a community college has several important advantages for students. To begin, the open admission policy makes it easier for students to enroll regardless of their prior academic record.

Attending community colleges costs less because of lower tuition and other fees than those at four-year colleges. Community college students on average paid $\$ 2,017$ in tuition and fees for the 2006-07 academic year, which is less than half the amount for students in public four-year universities $(\$ 5,685)$ and only about one-tenth of the tuition and fees for students in private fouryear universities $(\$ 20,492)$, according to the U.S. Department of Education.

Table 2 presents a comparison of tuition costs and other fees for the Federal Reserve's Eighth

\footnotetext{
2 The latest available data are used throughout the paper, which means that time periods may vary between different sections of the paper.
}

District. Mississippi has the lowest tuition among the states of the Eighth District. Attending a fouryear private college in Mississippi costs $\$ 12,300$ per year on average. Attending a four-year public college costs significantly less: $\$ 4,457$ per year. Community college tuition in Mississippi is $\$ 1,709$ per year. Even the state with the highest community college tuition in the District, Indiana, charges only $\$ 2,713$ per year. In comparison, tuition at a private four-year college in Indiana costs on average $\$ 22,060$ per year. Illinois has the highest tuition for four-year public universities in the District $(\$ 8,038)$.

In addition, most community college students live at home, thus saving the added room and board expenses incurred by students at other institutions. Finally, community colleges offer a more flexible curriculum, and their schedules include evening and weekend classes, which gives students an opportunity to attend college while working full-time.

\section{Community College Students}

The population of community college students is diverse and differs from the typical population at four-year colleges. Community college populations have 60 percent white, 15 percent black, 
and 14 percent Hispanic students. ${ }^{3}$ Forty-one percent of community college students are males. In comparison, students attending four-year colleges are more likely to be white (70 percent) and male (45 percent).

Because of the flexibility they offer and the relatively low monetary and time costs of attending, community colleges have more so-called nontraditional students than four-year colleges. Community college students are more likely to be older: 35 percent are 30 years old or older compared with 16 percent in four-year colleges. The average community college student is 28 years old, with a median age of 24 . The corresponding ages for students in four-year colleges are 24 and 21 years.

Only 31 percent of community college students are enrolled full-time, in part because students attending community colleges are more likely to also be working. In contrast, 63 percent of students at four-year colleges are enrolled fulltime. Only 21.4 percent of all community college students do not work, compared with 30.5 percent at four-year colleges. Furthermore, 40.8 percent of community college students work full-time, compared with 22.8 percent of their four-year college counterparts.

More students in community colleges are firstgeneration college students than are students attending four-year colleges. More than 40 percent of the former have parents with only a high school education or less. In contrast, only 27 percent of four-year college students have parents with a high school education or less.

Not surprisingly, most community college students attend an institution close to their home. They live on average 40 miles away from the college they attend. In comparison, students at fouryear institutions attend colleges on average 230 miles away from their home. More than 95 percent of community college students attend colleges in their home states compared with 83 percent of students at four-year colleges.

\footnotetext{
3 Unless noted otherwise, the data in this section are from the Center for Education Statistics, U.S. Department of Education, 2003-04 as presented in Horn and Nevill (2006).
}

\section{LABOR MARKET RETURNS}

What is the economic payoff to attending community college? The answer to this question is rather complicated, partly because of the lack of available data. Until 1990, the U.S. Census Bureau recorded only the number of years of education, making it impossible to identify individuals attending community college specifically. In the 1990 and 2000 U.S. censuses, the highest educational attainment was recorded instead of years of education. This makes it possible to focus on individuals with a completed AD. Still, this information does not make it possible to identify an institution students attended if they did not complete a degree.

Several available studies use different longitudinal survey data instead. Most of the surveys record data on various characteristics of respondents, starting with their teenage years and following them through the years. ${ }^{4}$ One limitation of these studies is that, given the timeline of surveys, they include only students who enrolled in community college soon after graduating from high school.

Most studies found that students who attended community college, but did not complete a degree, earn 9 to 13 percent more than those with only a high school diploma. The estimation technique usually attempts to control for differences in academic preparation between the two groups as measured by test scores and class rank. Furthermore, researchers found an increase in annual earnings of 5 percent to 8 percent associated with each year of education at a community college. This finding is particularly interesting because it is similar to the return to a year of schooling in a four-year college.

Jacobson, LaLonde, and Sullivan (2005) looked at a very different group-older, hightenure, displaced workers. Most retraining efforts for this group take place at community colleges. These researchers found that one year of community college schooling increases the long-term earnings of displaced workers by about 9 percent for men and about 13 percent for women com-

\footnotetext{
4 See Kane and Rouse (1999) for a survey of these studies and a more detailed description of data.
} 
pared with earnings for similar workers who did not attend community college. Another important fact reported by these authors is that technically oriented and math and science courses lead to a higher earnings payoff-about 14 percent for men and 29 percent for women-but less technically oriented courses yield very low and possibly zero returns.

\section{RETURNS TO AN ASSOCIATE'S DEGREE}

Another way to assess the value of a community college education is to determine how much more a person with an AD earns compared with a similar person with only a high school diploma. Separate studies by Kane and Rouse (1995) and Leigh and Gill (1997) estimated the labor market return to an $\mathrm{AD}$ is about 16 to 27 percent.

The much-larger dataset from the U.S. 2000 Census ${ }^{5}$ affords answers to more detailed questions. For instance, are there differences in labor market returns to an AD between different demographic groups? Are the returns the same across different cities? Data also allow looking at the differentials in hourly wages rather than annual earnings.

The sample consists of men and women 25 to 55 years of age with an AD or a high school diploma who live either in the 20 largest metropolitan areas of the United States (including St. Louis) or in large metropolitan areas of the Eighth District (Memphis, Little Rock, and Louisville).

A simple matching estimator was used to calculate, for each metropolitan area $j$, the rate of return to an AD. Intuitively, people who have an AD were matched with those who do not but who have otherwise similar demographic characteristics. We can ask, then, how their wages differ. It is assumed that productivity, which translates into wages, is a function of education and age, since older workers tend to have more work experience.

5 Data are from 2000 Public Use Micro Sample of the U.S. Census (see Ruggles et al., 2004).
More precisely, for an individual with age $x=X$ in metropolitan area $j$, we would like to estimate the causal effect of an $\mathrm{AD}(A D=1)$,

$$
\begin{aligned}
& \Delta(X, j)=E\left(y_{1} \mid x=X, A D=1, j\right) \\
& -E\left(y_{0} \mid x=X, A D=1, j\right),
\end{aligned}
$$

the difference between the wage of an individual with an $\mathrm{AD}$ and his or her potential wage if formal education stopped at the high school level. Here, $y_{1}$ is the logarithm of the worker's wage if the individual has an $\mathrm{AD}$, and $y_{0}$ is the logarithm of the worker's wage if the individual stops his or her education at high school. Of course, we cannot directly observe the second term in the above equation; we never observe what a person with an $\mathrm{AD}$ would have earned with only a high school education.

If, however, we are willing to eliminate selection problems by assumption (including the issue of ability bias that has received close attention in the literature), we have

$$
E\left(y_{0} \mid x=X, A D=1, j\right)=E\left(y_{0} \mid x=X, A D=0, j\right),
$$

This equation simply means that the wages of a person with an $\mathrm{AD}$, if he or she did not receive it, would have been the same as the wages of a similar person with a high school diploma. Thus, the mean return to an $\mathrm{AD}$ in a particular metropolitan area $j$, denoted as $\Delta(j)$, is

$$
\Delta(j)=\int \Delta(x \mid j) d F(x \mid j),
$$

where $d F(x \mid j)$ is the distribution of $x$ in the metropolitan area.

In principle, $\Delta(j)$ might vary across cities simply because of differences in the age distributions in these cities. Such differences would be of little interest, so to "standardize" the estimates, I use the national cumulative distribution function of $x$ and calculate

$$
\Delta_{n}(j)=\int \Delta(x \mid j) d F_{n}(x),
$$

where $d F_{n}(x)$ is derived from the national data. ${ }^{6}$

6 For more on this approach to a nonparametric estimation of returns to schooling, see Black, Kolesnikova, and Taylor (2009). 
Table 3

Labor Market Returns* to Associate's Degree (Relative to High School) for Women by Race

\begin{tabular}{lccc} 
Region/City & White & Black & Hispanic \\
\hline United States & 0.29 & 0.30 & 0.29 \\
20 largest metropolitan areas & & & 0.53 \\
Atlanta & 0.27 & 0.29 & 0.20 \\
Baltimore & 0.28 & 0.28 & 0.31 \\
Boston & 0.29 & 0.33 & 0.21 \\
Chicago & 0.25 & 0.23 & 0.24 \\
Dallas & 0.30 & 0.27 & 0.25 \\
Detroit & 0.32 & 0.19 & 0.20 \\
Houston & 0.24 & 0.45 & 0.30 \\
Los Angeles & 0.20 & 0.26 & 0.33 \\
Miami & 0.25 & 0.30 & 0.24 \\
Minneapolis & 0.23 & 0.28 & 0.28 \\
New York & 0.26 & 0.35 & 0.38 \\
Philadelphia & 0.28 & 0.24 & 0.18 \\
Phoenix & 0.24 & 0.33 & - \\
Pittsburgh & 0.29 & 0.19 & 0.36 \\
Riverside-San Bernardino & 0.31 & 0.40 & 0.28 \\
San Diego & 0.23 & 0.21 & - \\
San Francisco & 0.26 & 0.21 & - \\
Seattle & 0.25 & 0.29 & - \\
St. Louis & 0.24 & 0.43 & 0.39 \\
Washington & 0.23 & 0.26 & -37 \\
Eighth District large metropolitan & & 0.31 & -
\end{tabular}

NOTE: *The numbers can be interpreted as percentage increases in wages. (See footnote 7 for more information.)

SOURCE: Author's calculations. Data are from 2000 Public Use Micro Sample (PUMS) of the U.S. Census. Results are missing if data were insufficient because of small sample size.

This estimation is performed separately for men and women and for different racial groups.

One immediate feature of the results is that, though the estimated average returns to an $\mathrm{AD}$ are consistent with other researchers' findings, there are significant differences among demographic groups (Tables 3 and 4). Women of all races have higher returns to an $\mathrm{AD}$ than men do, which might be due to the fact that women are more likely to major in nursing and related health fields. The return to an $\mathrm{AD}$ also varies among racial groups. Hourly wages of white men with an $\mathrm{AD}$ are 18 percent higher than wages of white men who stopped their formal education at high school. ${ }^{7}$ The same returns are much

\footnotetext{
7 Tables 3 and 4 report differences in mean log wages between holders of ADs and high school graduates. Differences in mean log wages, called log points differences, approximate percentage differences.
} 


\section{Table 4}

Labor Market Returns* to Associate's Degree (Relative to High School) for Men by Race

\begin{tabular}{|c|c|c|c|}
\hline Region/City & White & Black & Hispanic \\
\hline United States & 0.18 & 0.25 & 0.27 \\
\hline \multicolumn{4}{|l|}{20 largest metropolitan areas } \\
\hline Atlanta & 0.21 & 0.26 & 0.39 \\
\hline Baltimore & 0.15 & 0.26 & 0.19 \\
\hline Boston & 0.17 & 0.06 & 0.25 \\
\hline Chicago & 0.10 & 0.21 & 0.19 \\
\hline Dallas & 0.24 & 0.28 & 0.29 \\
\hline Detroit & 0.21 & 0.22 & 0.34 \\
\hline Houston & 0.19 & 0.21 & 0.27 \\
\hline Los Angeles & 0.16 & 0.35 & 0.30 \\
\hline Miami & 0.30 & 0.25 & 0.30 \\
\hline Minneapolis & 0.17 & 0.27 & 0.32 \\
\hline New York & 0.11 & 0.24 & 0.21 \\
\hline Philadelphia & 0.15 & 0.17 & 0.32 \\
\hline Phoenix & 0.18 & 0.42 & 0.24 \\
\hline Pittsburgh & 0.16 & 0.17 & - \\
\hline Riverside-San Bernardino & 0.20 & 0.15 & 0.24 \\
\hline San Diego & 0.15 & 0.36 & 0.24 \\
\hline San Francisco & 0.12 & 0.48 & 0.23 \\
\hline Seattle & 0.04 & 0.22 & 0.17 \\
\hline St. Louis & 0.11 & 0.13 & - \\
\hline Washington & 0.18 & 0.22 & 0.16 \\
\hline \multicolumn{4}{|c|}{ Eighth District large metropolitan areas } \\
\hline Memphis & 0.16 & 0.22 & - \\
\hline Little Rock & 0.22 & - & - \\
\hline Louisville & 0.18 & 0.17 & - \\
\hline
\end{tabular}

NOTE: *The numbers can be interpreted as percentage increases in wages. (See footnote 7 for more information.)

SOURCE: Author's calculations. Data are from 2000 Public Use Micro Sample (PUMS) of the U.S. Census. Results are missing if data were insufficient because of small sample size.

higher for black and Hispanic men-25 and 27 percent higher, respectively.

Furthermore, the return to an $\mathrm{AD}$ is not the same across different cities in the United States. For example, white men with ADs are paid only 4 percent more than white high school graduates in Seattle but as much as 30 percent more in Miami. For Hispanic men, the return to an $\mathrm{AD}$ is 16 percent in Washington, D.C., but it is more than twice as much-39 percent-in Atlanta. Cross-city dif- ferentials for white women are not as large, but they are significant for minority women.

Tables 3 and 4 also present estimated returns to an AD in four large metropolitan areas of the Eighth District. White men with an AD earn on average 11 percent more in St. Louis, 16 percent more in Memphis, 22 percent more in Little Rock, and 18 percent more in Louisville than similar men with only a high school diploma. For black men, returns to an $\mathrm{AD}$ are 13 percent in St. Louis, 
22 percent in Memphis, and 17 percent in Louisville. Consistent with the rest of the country, women's returns are higher than men's. For example, black women in St. Louis with an AD earn 43 percent more than black women with only a high school education.

Why is there such a large variation in returns to an $\mathrm{AD}$ across cities? Although no formal research has been done on this topic, possible explanations might be locational differences in labor market conditions and industrial composition.

\section{DIFFERENT EDUCATIONAL PATHS}

Community college students have various educational goals and intentions when they enter college. Although many plan to obtain an AD, some students enroll to take just a few classes to improve their skills or to become certified in a certain field. Some intend to transfer to a fouryear institution without any formal community college credentials.

This ability of community colleges to offer students many options provides a unique opportunity to obtain postsecondary education for many students who would not have it otherwise. On the other hand, because the educational objectives of students—and, thus, their paths—are so different, it is difficult to track their progress through college and to assess the effect of community college education on their educational attainment and labor market outcomes. The fact that most students attend community colleges part-time and take longer to complete their program makes the task even more complicated.

Critics of the community college system often point out that a significant proportion of community college students earn relatively few college credits. Kane and Rouse (1999) calculated that the majority of community college students complete one year or less and 35 percent complete only one semester of study or less. The study also showed that fewer than half of community college students complete any degrees. In particular, about 15 percent receive a certificate, 16 percent complete an $\mathrm{AD}$, and another 16 percent eventually receive a bachelor's degree or higher. Kane and Rouse (1999) point out that, unlike their community college counterparts, almost 60 percent of four-year college entrants receive at least a bachelor's degree.

Does this mean that enrolling in a two-year college somehow reduces an individual's educational attainment? One view is that easy access to community college sidetracks students from a four-year college, where they are more likely to obtain a bachelor's degree. On the other hand, many nontraditional students who attend community college would not attend four-year colleges. For them, community colleges provide a chance for a postsecondary education they would not have had otherwise. Therefore, researchers argue, even if attending a community college instead of a four-year college might lower educational attainment for some students, more students have access to higher education, which raises overall educational attainment in society.

To better answer questions about the effect of community colleges on educational attainment, it is necessary to consider students' intentions toward their educational objectives together with their outcomes. The problem is a lack of reliable data that measure students' goals and preparation.

The U.S. Department of Education has attempted to study educational outcomes of community college students. Its report used data from several sources, including those tracking students over time (Hoachlande et al., 2003). The study found that about 90 percent of students entering community college intended to obtain a formal credential or to transfer to a four-year college. One could argue that it is more reasonable to consider completion rates only for those who intended to obtain a degree in the first place. The report estimated that, depending on the data used, between 51 percent and 63 percent of these students had fulfilled their expectations within six to eight years after initial enrollment. In particular, about 11 percent had earned a certificate, 17 percent to 18 percent had earned an $\mathrm{AD}, 11$ percent to 28 percent (depending on the data used) had attained a bachelor's degree or higher, and 12 percent to 13 percent had transferred to a four-year college without attaining a formal degree.

Keeping in mind that a primary goal of twoyear colleges is to prepare students to continue 
their studies at four-year institutions, it is particularly important to evaluate their transfer rates. The U.S. Department of Education (Hoachlande et al., 2003) report indicated that, overall, about 29 percent of community college students had transferred to four-year colleges. Interestingly, 51 percent of those who intended to complete a bachelor's degree when they first started had transferred. At the time data were collected, 80 percent of those who transferred either obtained a bachelor's degree or were still working toward it.

What about the students who left community college without any formal credential? This amounts to more than half of those who started classes. According to the report, about one-third of this group said that postsecondary education improved their salary. For 47 percent, attending community college led to increased job opportunities. About 43 percent reported improvement in job performance, and 47 percent said they had more job responsibilities.

Students who did receive a certificate or a degree were more likely to be satisfied with their outcomes. About 80 percent of them said their salaries had increased. Almost 85 percent reported having a better job or more responsibilities.

\section{FROM A COMMUNITY COLLEGE TO A BACHELOR'S DEGREE}

As discussed previously, even though community colleges initially were introduced to help prepare students for four-year colleges, fewer than a third of community college students transfer to four-year colleges. Still, it is important to compare the outcomes of students who transfer to a four-year institution with the outcomes of their counterparts who began at a four-year institution.

A recent study by Long and Kurlaender (2008) evaluates whether there is what the authors term a "community college penalty." The study uses a unique longitudinal dataset that includes everyone who entered Ohio public institutions of higher education in the fall of 1998 with follow-up over the next nine years. It provides information on students' high school preparation, entrance examinations, degree intentions, family background, college performance and, finally, degree completion. As long as students transfer between Ohio's public colleges and universities, they remain in the dataset. This makes it possible to track most students' progress from starting postsecondary education at a community college to receiving a bachelor's degree from a four-year college.

The study finds that there is indeed a "penalty" resulting from beginning postsecondary education at a community college. The rates of dropping out or "stopping out" without a degree are much higher for those who start at community colleges than for those who start at four-year institutions. For example, community college students were 36 percent less likely to obtain a bachelor's degree than similar students who started at four-year colleges.

One possible explanation for this result is that four-year college students start with an intention to graduate while community college students have different educational objectives. The study finds, however, that even community college students who expressed an intention to obtain a four-year bachelor's degree are significantly less likely to do so within nine years of starting their postsecondary studies. Only 26 percent of this group have a bachelor's degree nine years after starting their postsecondary education. To put it in perspective, 50 percent and 73 percent of those who start at nonselective and selective four-year institutions, respectively, obtain a bachelor's degree. In addition, students who start at community colleges have fewer total earned credits than students who start at four-year colleges.

The observed differences in educational outcomes may occur because of the differences between the students at two-year and four-year institutions. Demographic, family, and other characteristics of students who begin at community colleges differ from those of students who begin at four-year institutions. Such differences might lead to a selection bias of the estimates. However, the negative effect of starting postsecondary education at a community college remains even after adjusting for selection bias by controlling for students' race, gender, age, ability (measured by ACT scores), and family income. The authors find "a persistent community college 
Table 5

\section{Proportion of Bachelor's Degree Holders with Associate's Degrees by Region of Residence}

\begin{tabular}{lcc} 
& \multicolumn{2}{c}{ Proportion of bachelor's degree holders } \\
\cline { 2 - 3 } Region & With AD (\%) & Who attended community college (\%) \\
\hline New England & 14 & 31 \\
Middle Atlantic & 15 & 34 \\
East North Central & 15 & 42 \\
West North Central & 15 & 44 \\
South Atlantic & 18 & 45 \\
East South Central & 17 & 43 \\
West South Central & 15 & 48 \\
Mountain & 15 & 50 \\
Pacific & 20 & 58
\end{tabular}

SOURCE: Author's calculations. Data are from NSCG (2003).

penalty," but they suggest that "it is worth comparing the size of the penalty to the difference in costs at two-year versus four-year institutions."

\section{LONG-TERM EDUCATIONAL OUTCOMES}

Few community college students go on to receive a bachelor's degree. Still, some successfully transfer to four-year colleges and obtain a bachelor's degree or higher. This section compares these individuals with those who start postsecondary education at traditional four-year colleges and analyzes their long-term educational outcomes.

The NSCG is a joint project of the U.S Census Bureau and the National Science Foundation. The 2003 survey included a sample of respondents to the 2000 Decennial Census long form who indicated they have a bachelor's degree or higher in any field of study. The survey collected detailed information about their education, current and past employment, current salary, and demographic characteristics. In particular, the dataset reports educational background characteristics, such as type of college attended, major field of study, number of degrees, and the highest degree received. Most importantly, for my purposes, it identifies respondents who have an $\mathrm{AD}$ or attended a com- munity college. One shortcoming of these data, however, is a lack of family background information and ability measures.

Among people who have at least a bachelor's degree, 17 percent report having received an AD. (I assume here that they started their postsecondary education at a community college and, after receiving an $\mathrm{AD}$, continued their education at a four-year college.) The rest of this section compares this group with the rest of the respondents with at least a bachelor's degree. ${ }^{8}$ I start the comparison of the two groups by presenting some descriptive statistics.

Table 5 reports the proportion of respondents with a bachelor's degree who either attended a community college or have an $\mathrm{AD}$; this group is classified according to region of residence. ${ }^{9}$ Between 14 and 20 percent of four-year college graduates have an $\mathrm{AD}$, depending on the region. Bachelor's degree holders in the Pacific and South Atlantic regions are most likely to have an $\mathrm{AD}$

8 The dataset also identifies individuals who attended a community college but does not identify what they were studying. It is impossible to know whether a person took classes for credit in preparation for college or not. Because of this limitation, I ignore these individuals' community college experience.

9 The definition of the region in this context is provided in Appendix A. "Region" is the smallest geographic unit of analysis available in the NSCG dataset. 


\section{Table 6}

\section{Proportion of Bachelor's Degree Holders with Associate's Degree by Region of Birth}

\begin{tabular}{lcc} 
& \multicolumn{2}{c}{ Proportion of bachelor's degree holders } \\
\cline { 2 - 4 } Region & With AD (\%) & Who attended community college (\%) \\
\hline New England & 15 & 34 \\
Middle Atlantic & 16 & 38 \\
East North Central & 15 & 44 \\
West North Central & 16 & 44 \\
South Atlantic & 18 & 47 \\
East South Central & 16 & 42 \\
West South Central & 15 & 48 \\
Mountain & 18 & 48 \\
Pacific & 24 & 60
\end{tabular}

SOURCE: Author's calculations. Data are from NSCG (2003).

(20 percent and 18 percent, respectively), while New England residents with a bachelor's degree are least likely to have an $\mathrm{AD}$ (14 percent). As many as 58 percent of bachelor's degree holders attended a community college at some point in the Pacific region, but only 31 percent did in New England.

Table 6 reports similar statistics by region of birth. People with a bachelor's degree who were born in the Pacific region are significantly more likely to attend community college (60 percent) or have an $\mathrm{AD}$ (24 percent) than people who were born in other regions. This is not surprising given that the Pacific region includes California, the state with the highest community college enrollment.

Figure 1 presents a distribution of parental education. Consistent with other studies, I find that $\mathrm{AD}$ holders are much more likely to be firstgeneration college students than those who do not have an $\mathrm{AD}$. They are also more likely to have parents with a level of education less than a college degree.

Next, I examine whether there are differences in educational choices between those who obtained an $\mathrm{AD}$ before enrolling in a four-year college and those who did not. Table 7 summarizes the types of four-year institutions that respondents attended. The Carnegie Foundation Classification of Insti- tutions of Higher Education is used to categorize universities as Research Universities (I and II), Doctorate Granting (I and II), Master's Granting (I and II), Liberal Arts (I and II), and Associates of Art Colleges that include community colleges. ${ }^{10}$

While direct comparison of the quality of education provided by different universities is difficult, traditionally research and doctorategranting universities are perceived as being more selective and having better resources than master'sgranting and liberal arts colleges.

Table 7 shows that people with a prior AD were significantly less likely to attend Research I universities (18 percent vs. 26 percent) and slightly less likely to attend Doctorate-Granting universities (6 percent vs. 7 percent). On the other hand, a much higher proportion attended Master'sGranting universities (36 percent vs. 27 percent). It also seems that people with a prior $\mathrm{AD}$ were much less likely to attend more selective Liberal Arts I colleges than their counterparts (1 percent vs. 6 percent). To sum up, it appears that $A D$ recipients attended less-selective (and perhaps less-expensive) institutions for their bachelor's studies. Figure 2 shows that students with an $\mathrm{AD}$ are also more likely to be enrolled in public

${ }^{10}$ See Appendix B for definitions of the Carnegie Foundation Classification of Institutions of Higher Education categories. 
Figure 1

\section{Parents' Education}
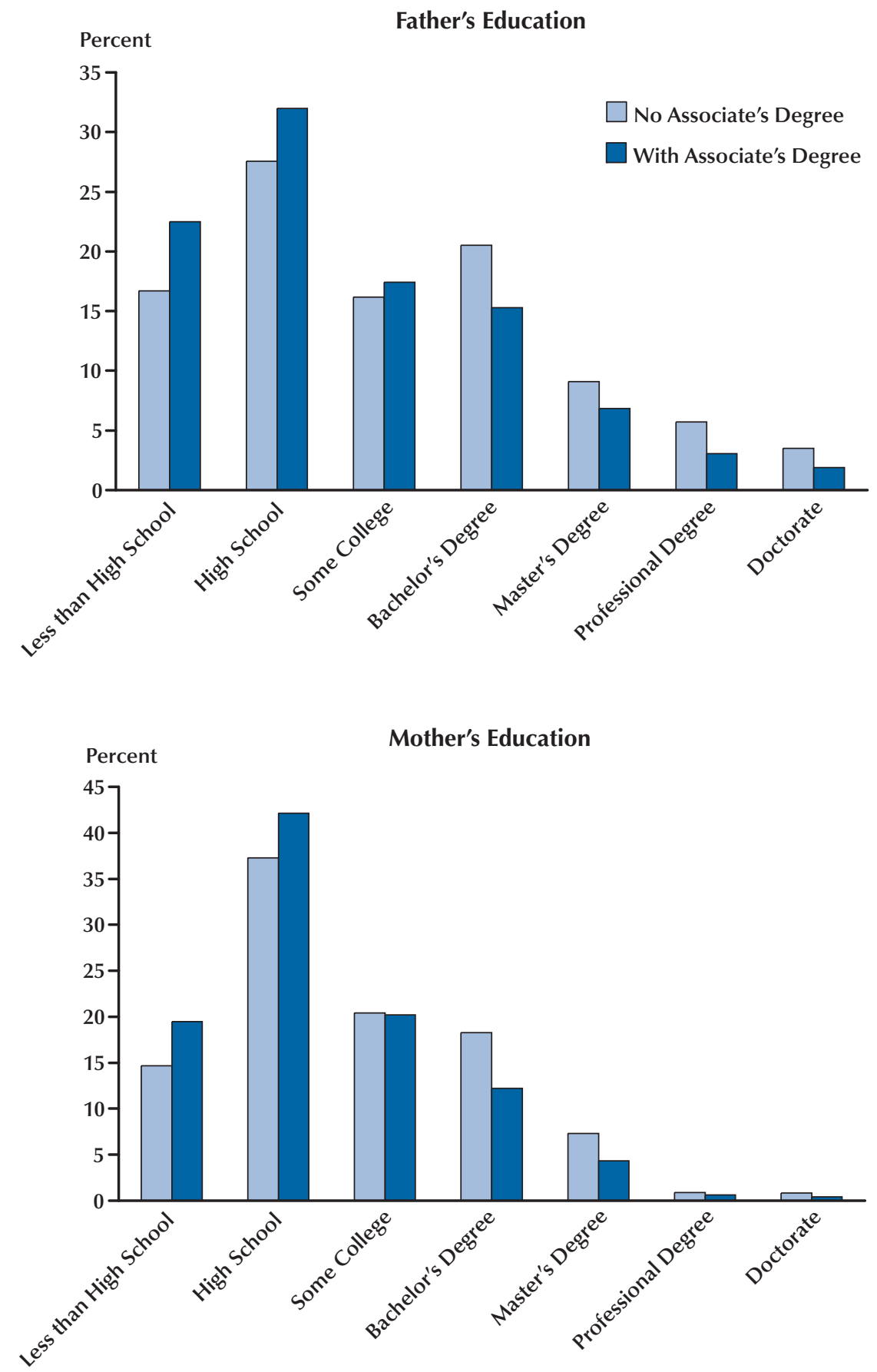
Figure 2

Public or Private Institution of Bachelor's Degree

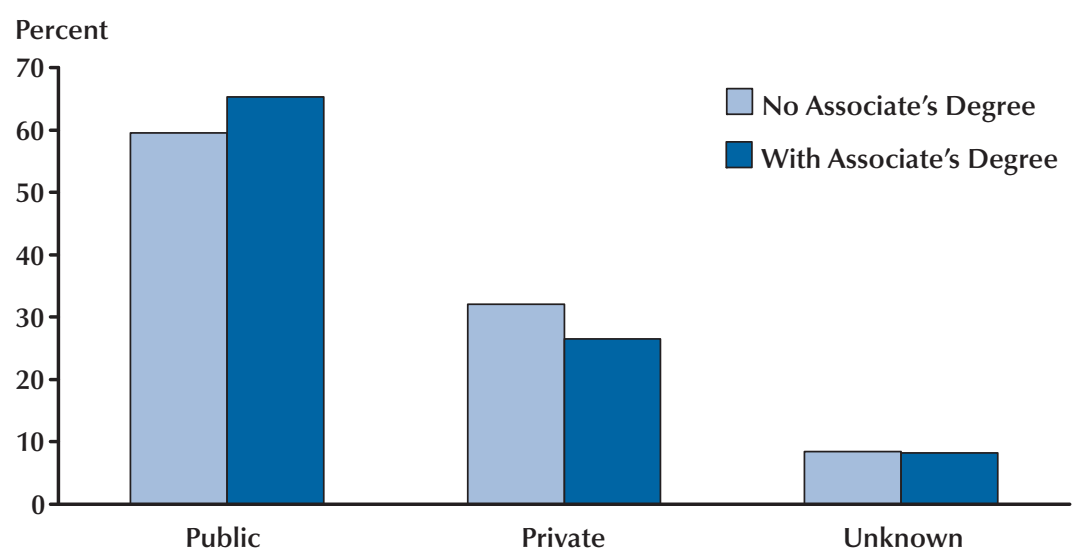

Table 7

Institution Awarding First Bachelor's Degree

\begin{tabular}{lccr} 
Carnegie Classification of Institution & $\begin{array}{c}\text { All bachelor's } \\
\text { degree holders (\%) }\end{array}$ & No AD (\%) & With AD (\%) \\
\hline Research University I & 24.57 & 25.88 & 7.29 \\
Research University II & 7.39 & 6.89 & 6.74 \\
Doctorate-Granting I & 6.68 & 5.57 & 5.72 \\
Doctorate-Granting II & 5.78 & 26.95 & 36.02 \\
Master's I & 28.5 & 2.03 & 3.23 \\
Master's II & 2.24 & 5.86 & 1.32 \\
Baccalaureate (Liberal Arts) I & 5.08 & 7.51 & 8.18 \\
Baccalaureate (Liberal Arts) II & 7.62 & 0.15 & 0.84 \\
Associate of Art Colleges & 0.27 & 2.49 \\
Other & 2.62 & 9.17 \\
Missing information & 9.23 & & 3.35 \\
NOTE: See Appendix B for descriptions of the classifications. & & 9.54 \\
SOURCE: Author's calculations. Data are from NSCG (2003). & &
\end{tabular}


Table 8

Distribution of Major Fields of Study of First Bachelor's Degree

\begin{tabular}{|c|c|c|c|}
\hline Major field of study & $\begin{array}{l}\text { All bachelor's } \\
\text { egree holders }(\%)\end{array}$ & No AD (\%) & With AD (\%) \\
\hline Computer and math sciences & 3.86 & 3.87 & 3.82 \\
\hline Computer and information sciences & 1.99 & 1.86 & 2.66 \\
\hline Mathematics and statistics & 1.87 & 2.01 & 1.16 \\
\hline Biological, agricultural, environmental & 6.2 & 6.48 & 4.87 \\
\hline Agricultural and food sciences & 0.8 & 0.83 & 0.69 \\
\hline Biological sciences & 4.97 & 5.27 & 3.54 \\
\hline Environmental life sciences & 0.43 & 0.38 & 0.64 \\
\hline Physical and related sciences & 2.9 & 3.14 & 1.71 \\
\hline Chemistry, except biochemistry & 1.51 & 1.67 & 0.73 \\
\hline Earth, atmospheric, and ocean sciences & 0.57 & 0.59 & 0.46 \\
\hline Physics and astronomy & 0.62 & 0.68 & 0.32 \\
\hline Other physical sciences & 0.2 & 0.2 & 0.2 \\
\hline Social and related sciences & 14 & 14.27 & 12.69 \\
\hline Economics & 2.16 & 2.4 & 1.04 \\
\hline Political and related sciences & 3.11 & 3.34 & 2.01 \\
\hline Psychology & 4.61 & 4.55 & 4.9 \\
\hline Sociology and anthropology & 2.76 & 2.64 & 3.32 \\
\hline Other social sciences & 1.36 & 1.34 & 1.42 \\
\hline Engineering & 7.7 & 7.99 & 6.35 \\
\hline Aerospace, aeronautical, and astronautical & 0.29 & 0.31 & 0.22 \\
\hline Chemical engineering & 0.6 & 0.68 & 0.22 \\
\hline Civil and architectural engineering & 1.16 & 1.19 & 1.02 \\
\hline Electrical and computer engineering & 2.39 & 2.43 & 2.2 \\
\hline Industrial engineering & 0.48 & 0.5 & 0.41 \\
\hline Mechanical engineering & 1.76 & 1.81 & 1.48 \\
\hline Other engineering & 1.02 & 1.07 & 0.8 \\
\hline Health, science education, technology & 9.57 & 9.46 & 10.21 \\
\hline Health & 6.6 & 6.51 & 7.08 \\
\hline Science and mathematics teacher education & 1.15 & 1.19 & 0.97 \\
\hline Technology and technical fields & 1 & 0.88 & 1.62 \\
\hline Other science- and education-related fields & 0.82 & 0.88 & 0.54 \\
\hline Business, management, art & 55.75 & 54.79 & 60.32 \\
\hline Management and administration fields & 17.61 & 16.6 & 22.45 \\
\hline Education, except science and math teacher education & 13.51 & 13.39 & 14.08 \\
\hline Social service and related fields & 2.28 & 2.19 & 2.71 \\
\hline Sales and marketing fields & 2.61 & 2.56 & 2.86 \\
\hline Art and humanities fields & 12.69 & 13.22 & 10.15 \\
\hline Other non-science and education fields & 7.05 & 6.83 & 8.07 \\
\hline
\end{tabular}

SOURCE: Author's calculations. Data are from NSCG (2003). 


\section{Table 9}

Proportion of Males by Major Field of Study

\begin{tabular}{|c|c|c|c|}
\hline Major field of study & $\begin{array}{l}\text { bachelor's } \\
\text { e holders (\%) }\end{array}$ & No AD (\%) & With AD (\%) \\
\hline Computer and math sciences & 64 & 64 & 64 \\
\hline Computer and information sciences & 67 & 69 & 61 \\
\hline Mathematics and statistics & 60 & 59 & 71 \\
\hline Biological, agricultural, environmental & 57 & 57 & 59 \\
\hline Agricultural and food sciences & 68 & 66 & 76 \\
\hline Biological sciences & 54 & 54 & 53 \\
\hline Environmental life sciences & 71 & 70 & 75 \\
\hline Physical and related sciences & 74 & 74 & 73 \\
\hline Chemistry, except biochemistry & 68 & 68 & 64 \\
\hline Earth, atmospheric, and ocean sciences & 81 & 80 & 86 \\
\hline Physics and astronomy & 84 & 84 & 81 \\
\hline Other physical sciences & 64 & 64 & 65 \\
\hline Social and related sciences & 48 & 49 & 46 \\
\hline Economics & 72 & 73 & 67 \\
\hline Political and related sciences & 63 & 63 & 62 \\
\hline Psychology & 33 & 33 & 32 \\
\hline Sociology and anthropology & 37 & 34 & 46 \\
\hline Other social sciences & 52 & 53 & 51 \\
\hline Engineering & 89 & 89 & 89 \\
\hline Aerospace, aeronautical, and astronautical & 92 & 93 & 83 \\
\hline Chemical engineering & 80 & 80 & 67 \\
\hline Civil and architectural engineering & 89 & 88 & 91 \\
\hline Electrical and computer engineering & 90 & 89 & 91 \\
\hline Industrial engineering & 85 & 84 & 91 \\
\hline Mechanical engineering & 93 & 93 & 92 \\
\hline Other engineering & 88 & 89 & 83 \\
\hline Health, science education, technology & 37 & 37 & 37 \\
\hline Health & 22 & 23 & 21 \\
\hline Science and mathematics teacher education & 51 & 51 & 51 \\
\hline Technology and technical fields & 86 & 86 & 87 \\
\hline Other science- and education-related fields & 75 & 74 & 76 \\
\hline Business, management, art & 45 & 45 & 47 \\
\hline Management and administration fields & 63 & 64 & 61 \\
\hline Education, except science and math teacher education & 22 & 22 & 25 \\
\hline Social service and related fields & 48 & 49 & 45 \\
\hline Sales and marketing fields & 57 & 59 & 51 \\
\hline Art and humanities fields & 42 & 42 & 41 \\
\hline Other non-science and education fields & 44 & 42 & 51 \\
\hline
\end{tabular}


Table 10

\section{Age at Attaining Degrees}

\begin{tabular}{lccc} 
& All & No AD & With AD \\
\hline Age at first bachelor's degree (years) & & & 29.5 \\
Mean & 26.8 & 26.2 & 7.3 \\
Standard deviation (SD) & 5.3 & 4.6 & 16 \\
Minimum & 15 & 15 & 74 \\
Maximum & 74 & 71 & 23 \\
10 percent & 23 & 22 & 25 \\
25 percent & 24 & 24 & 27 \\
Median & 25 & 25 & 32 \\
75 percent & 28 & 27 & 40 \\
90 percent & 32 & 30 & 31.7 \\
Age at highest degree (years) & & & 8.3 \\
Mean & 29.7 & 29.3 & 16 \\
SD & 7.2 & 6.8 & 73 \\
Minimum & 15 & 15 & 24 \\
Maximum & 77 & 77 & 26 \\
10 percent & 23 & 23 & 29 \\
25 percent & 25 & 25 & 36 \\
Median & 27 & 27 & 44 \\
75 percent & 32 & 31 & \\
90 percent & 40 & 38 & \\
SOURCE: Author's calculations. Data are from NSCG $(\mathbf{2 0 0 3 ) .}$ & & \\
\hline
\end{tabular}

colleges than students who do not have an AD and less likely to attend private colleges.

Are there differences in major fields of study between the two groups? One of the main objectives of community colleges is to prepare students for four-year college studies. Do students who have taken classes at a community college choose different fields of study than students who did not go to community college before attending a four-year institution?

Fortunately, NSCG data provide detailed information on respondents' degree majors. As shown in Table 8, fewer people with an AD major in sciences and engineering than people with no AD. Instead, people with an AD are more likely to major in health, technology, and management than their counterparts. Preference for the health and technology fields is expected, given that community colleges often focus more on these disciplines. It is somewhat surprising that so many more $\mathrm{AD}$ holders choose to major in management than people without an $\mathrm{AD}$ (22 percent vs. 17 percent). Interestingly, there is little difference in gender distribution across major fields of study between the two groups (Table 9). There are some exceptions, however. More women with ADs choose to major in computer and information sciences, economics, aerospace engineering, chemical engineering, and marketing than women without an AD; and more men with ADs choose to major in mathematics and statistics, agriculture, environmental and earth sciences, sociology, and industrial engineering than men without an $\mathrm{AD}$. It is hard to know whether this is a result of stu- 
Figure 3

Number of Degrees (Bachelor's and Higher)

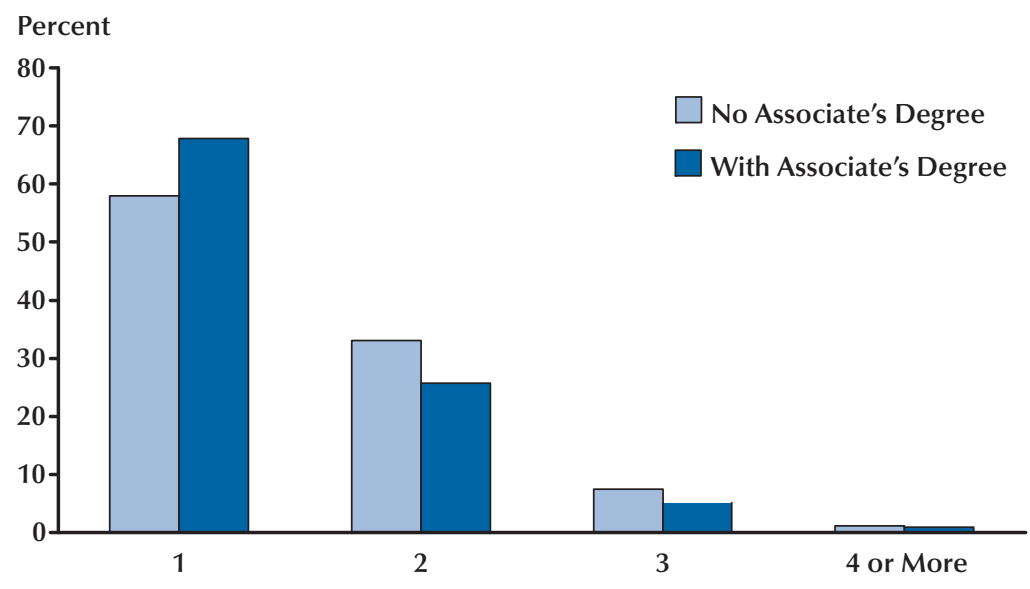

Figure 4

\section{Highest Degree Attained}

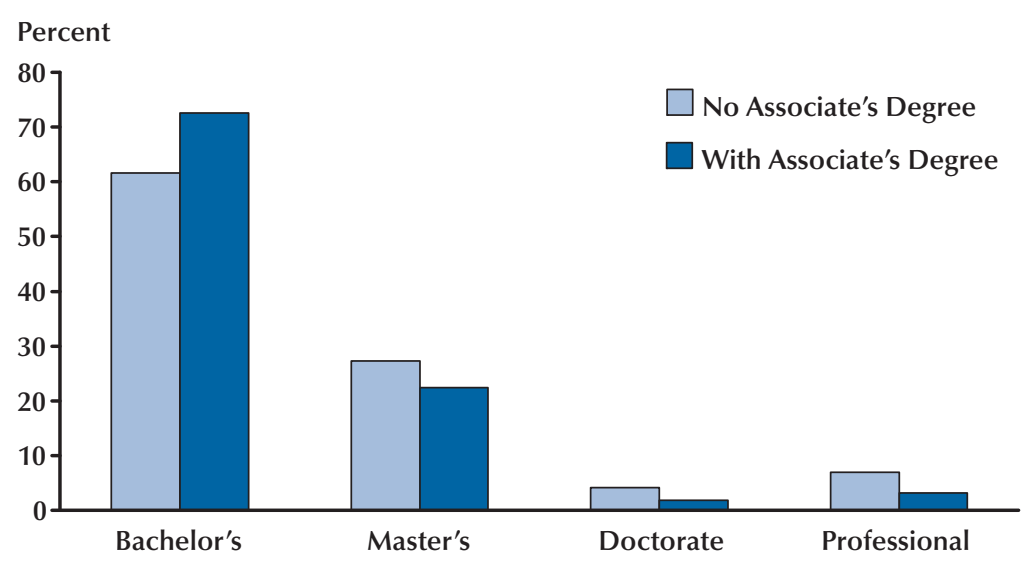


Table 11

Years from Bachelor's Degree to Advanced Degree

\begin{tabular}{|c|c|c|c|}
\hline & All & No AD & With AD \\
\hline \multicolumn{4}{|c|}{ Years from bachelor's degree to master's degree } \\
\hline Mean & 7.8 & 7.9 & 7.4 \\
\hline Standard deviation (SD) & 6.8 & 6.9 & 6.6 \\
\hline \multicolumn{4}{|c|}{ Years from bachelor's degree to doctorate } \\
\hline Mean & 11.1 & 10.9 & 12.8 \\
\hline SD & 7.0 & 6.9 & 8.5 \\
\hline \multicolumn{4}{|c|}{ Years from bachelor's degree to professional degree } \\
\hline Mean & 5.4 & 5.4 & 5.3 \\
\hline SD & 4.4 & 4.4 & 4.8 \\
\hline
\end{tabular}

SOURCE: Author's calculations. Data are from NSCG (2003).

\section{Table 12}

\section{Proportion of Associate's Degree Holders by Highest Degree}

\begin{tabular}{lc} 
Highest degree & With AD (\%) \\
\hline Bachelor's degree & 20.7 \\
Master's degree & 14.3 \\
Doctorate & 5.8 \\
Professional & 9.5
\end{tabular}

SOURCE: Author's calculations. Data are from NSCG (2003).

dents' exposure to some subjects before entering a four-year institution or other effects on some students' choice of a major field of study.

Not surprisingly, AD holders are older on average when they obtain a bachelor's degree. Their mean age is 29.5 years, compared with the mean age of 26.2 years of those who obtain a bachelor's degree without an AD (Table 10).

Almost 70 percent of bachelor's degree holders with an AD do not continue their education beyond their first bachelor's degree. This contrasts with the fewer than 60 percent of their counterparts without an AD (Figure 3). A higher proportion of people with no AD go on to receive a master's degree, a doctorate, or a professional degree (e.g., J.D. or M.D.) (Figure 4). Table 11 shows that, for those who continued beyond a bachelor's degree, it took slightly less time on average to obtain a master's or a professional degree if a person had an $\mathrm{AD}$ but longer to finish a Ph.D. program.

Table 12 presents another way to compare the highest education levels of people with and without an AD. Among people with only a bachelor's degree, about 21 percent have a prior AD. Among those who received a master's degree, only 14.3 percent have an AD. The proportion of people with an $\mathrm{AD}$ is even smaller among those with a doctorate or a professional degree (5.8 and 9.5 percent, respectively).

\section{LONG-TERM LABOR MARKET OUTCOMES}

This section compares labor market outcomes of people with an $\mathrm{AD}$ who proceeded to receive a bachelor's degree or higher and the labor market outcomes of their counterparts with no AD. In particular, it concentrates on one measure of labor market outcome-annual salary.

This analysis considers only individuals of prime age (23 to 55 years old) who are employed. Since salaries are top-coded in the NSCG dataset, those above the 95th percentile of salary distribution are omitted from the sample, as are those 
Table 13

Salaries (in US\$) by Education Level

\begin{tabular}{lccc} 
& All & No AD & With AD \\
\hline A. All & & & 53,696 \\
Mean & 57,686 & 58,559 & 26,597 \\
Standard deviation (SD) & 29,660 & 30,218 & 52,022 \\
B. Bachelor's degree & & 26,029 \\
Mean & 54,126 & 54,667 & 28,855 \\
SD & 28,319 & & 56,997 \\
C. Master's degree & & & 26,185 \\
Mean & 60,676 & 61,323 & 29,030 \\
SD & 28,663 & & 62,906 \\
D. Doctorate & & 71,246 & 28,851 \\
Mean & 70,711 & 29,832 & \\
SD & 29,837 & & 70,349 \\
E. Professional degree & & 79,491 & 34,799 \\
Mean & 78,705 & 36,793 &
\end{tabular}

SOURCE: Author's calculations. Data are from NSCG (2003).

below the 5th percentile, to maintain distribution symmetry. Thus, individuals who earn less than $\$ 10,000$ or more than $\$ 150,000$ per year are not included.

Table 13 shows the average annual salary by education level for the full sample and then separately for individuals with and without an AD. As expected and well documented in many other studies, people with a higher level of education have, on average, higher earnings. Bachelor's degree holders earn $\$ 54,126$ per year; people with master's degrees earn $\$ 60,676$ per year; people with a doctorate earn $\$ 70,711$ per year, and people with professional degrees earn $\$ 78,705$ per year, on average. Remarkably, annual salaries for individuals with an $\mathrm{AD}$ differ from those without an $\mathrm{AD}$ for all education levels. Regardless of the highest degree, people who started their postsecondary education with an $\mathrm{AD}$ earn less on average than those who started at a four-year college. The difference is particularly large for those with a doctorate or a professional degree.
A regression analysis can be used to better understand this phenomenon. In particular, I estimate the following equation:

$$
S=\beta_{0}+\beta_{1} * X+\beta_{1} * I_{A D}+\varepsilon,
$$

where $S$ is an individual's annual salary in dollars, $X$ is a vector of various characteristics that will be defined shortly, and $I_{A D}$ is an indicator of whether a person has an $\mathrm{AD}$, in which case it is equal to 1 ; otherwise, it is 0 . The goal is to compare individuals with the same characteristics $X$ but different values of an indicator $I_{A D}, 0$ or 1 . The question is how an $\mathrm{AD}$ affects one's salary. Relevant characteristics include age, gender, race, major field of study, and highest degree attained.

The estimation results of the above equation are reported in Table 14, panel A. The dependent variable is salary $S$. The results indicate that an annual salary increases by about $\$ 542$ per year as people age and accumulate more work experience. Women, on average, earn $\$ 12,137$ per year less than men with similar characteristics. Minority groups earn less compared with whites. The 
Table 14

Regression Analysis: Effects of Various Factors on Salary

\begin{tabular}{|c|c|c|c|}
\hline & Coefficient & Standard error & $t$-Statistic \\
\hline \multicolumn{4}{|l|}{ A. All } \\
\hline Age & 541.9 & 13.7 & 39.6 \\
\hline Woman & -12136.5 & 233.5 & -52.0 \\
\hline Black & -4943.0 & 410.5 & -12.0 \\
\hline Hispanic & -5768.8 & 460.1 & -12.5 \\
\hline Asian & -2558.6 & 416.9 & -6.1 \\
\hline Associate's degree & -3854.1 & 283.1 & -13.6 \\
\hline \multicolumn{4}{|l|}{ Controls } \\
\hline Major field of study & Yes & & \\
\hline Highest degree & Yes & & \\
\hline Number of observations & 59,346 & & \\
\hline Adjusted $R^{2}$ & 0.22 & & \\
\hline \multicolumn{4}{|l|}{ B. Bachelor's degree } \\
\hline Age & 487.6 & 17.6 & 27.73 \\
\hline Woman & -12724.9 & 300.1 & -42.4 \\
\hline Black & -6017.6 & 522.7 & -11.5 \\
\hline Hispanic & -6807.9 & 577.8 & -11.8 \\
\hline Asian & -3267.3 & 565.7 & -5.78 \\
\hline Associate's degree & -3620.8 & 346.0 & -10.46 \\
\hline Controls: Major field of study & Yes & & \\
\hline Number of observations & 34,067 & & \\
\hline Adjusted $R^{2}$ & 0.19 & & \\
\hline \multicolumn{4}{|l|}{ C. Master's degree } \\
\hline Age & 574.1 & 24.3 & 23.6 \\
\hline Woman & -11460.2 & 421.3 & -27.2 \\
\hline Black & -2198.1 & 716.5 & -3.1 \\
\hline Hispanic & -3549.5 & 865.6 & -4.1 \\
\hline Asian & -980.5 & 707.4 & -1.4 \\
\hline Associate's degree & -3379.1 & 536.7 & -6.3 \\
\hline Controls: Major field of study & Yes & & \\
\hline Number of observations & 17,803 & & \\
\hline Adjusted $R^{2}$ & 0.23 & & \\
\hline
\end{tabular}


Table 14, cont'd

Regression Analysis: Effects of Various Factors on Salary

\begin{tabular}{lccc} 
& Coefficient & Standard error & t-Statistic \\
\hline D. Doctorate & & & 18.5 \\
Age & 1078.1 & 58.4 & -9.3 \\
Woman & -8176.1 & 884.1 & -4.2 \\
Black & -7725.4 & 1839.1 & -1.6 \\
Hispanic & -3055.8 & 1937.8 & -3.17 \\
Asian & -3544.6 & 1116.6 & -5.7 \\
Associate's degree & -9565.3 & 1679.5 & \\
Controls: Major field of study & Yes & & \\
Number of observations & 4,521 & & 12.1 \\
Adjusted $R^{2}$ & 0.21 & & -5.9 \\
E. Professional degree & & 81.7 & -0.8 \\
Age & 984.4 & 1349.9 & -1.1 \\
Woman & -7949.2 & 2921.2 & -1.0 \\
Black & -2325.0 & 2775.5 & -3.9 \\
Hispanic & -3006.2 & 2393.2 & \\
Asian & -2473.6 & 2416.5 & \\
Associate's degree & -9423.2 & & \\
Controls: Major field of study & Yes & & \\
Number of observations & 2,955 & & \\
Adjusted $R^{2}$ & 0.08 & & \\
\hline
\end{tabular}

annual salary of blacks is $\$ 4,943$ lower on average than that of comparable whites. The corresponding difference for Hispanics is $\$ 5,769$, and it is $\$ 2,559$ for Asians. These facts are well documented in the economics literature. The most striking finding, however, is that even when other factors are controlled, people with an AD earn $\$ 3,854$ less per year than their counterparts with no AD. All coefficients are statistically significant at a 5 percent level or better.

The same equation is also estimated separately for each education-level group: bachelor's degree, master's degree, doctoral degree, and professional degree. Panels B through E of Table 14 show the results of the estimations. The same pattern is observed for each education-level group: Older workers earn more; women and minorities earn less. More importantly, those who earn an $\mathrm{AD}$ and then a more-advanced degree have lower earnings than those who earn a bachelor's degree or higher but no AD. For example, bachelor's degree holders earn $\$ 3,621$ less per year when they have a prior AD. Strikingly, earning gaps are observed even for those community college students who receive a doctorate or a professional degree. Their salaries are $\$ 9,565$ and $\$ 9,423$ lower, respectively, than salaries of their counterparts who started at a traditional four-year college.

One possible explanation for the salary disparity is that the quality of education differs for the two groups. For example, labor markets might assign an additional premium for a degree from an elite college. Controls were included for the type of institution awarding a bachelor's degree to test this possibility. Results remain virtually unchanged, which allows rejection of this explanation. ${ }^{11}$

\footnotetext{
11 These results are not reported here but are available from the
} author upon request. 
Table 15

Regression Analysis: Effects of Work Experience

\begin{tabular}{|c|c|c|c|}
\hline & Coefficient & Standard error & $t$-Statistic \\
\hline \multicolumn{4}{|l|}{ A. All } \\
\hline Experience & 605.2 & 13.4 & 45.2 \\
\hline Woman & -12100.4 & 232.5 & -52.0 \\
\hline Black & -4342.6 & 409.1 & -10.6 \\
\hline Hispanic & -5412.6 & 458.6 & -11.8 \\
\hline Asian & -3018.7 & 414.9 & -7.3 \\
\hline Associate's degree & -2426.1 & 281.2 & -8.6 \\
\hline \multicolumn{4}{|l|}{ Controls } \\
\hline Major field of study & Yes & & \\
\hline Highest degree & Yes & & \\
\hline Number of observations & 59,346 & & \\
\hline Adjusted $R^{2}$ & 0.23 & & \\
\hline \multicolumn{4}{|l|}{ B. Bachelor's degree } \\
\hline Experience & 574.8 & 17.2 & 33.4 \\
\hline Woman & 12681.1 & 298.6 & -42.5 \\
\hline Black & -5583.1 & 520.2 & -10.7 \\
\hline Hispanic & -6345.7 & 575.4 & -11.0 \\
\hline Asian & -3627.2 & 562.9 & -6.4 \\
\hline Associate's degree & -2268.7 & 342.8 & -6.6 \\
\hline Controls: Major field of study & Yes & & \\
\hline Number of observations & 34,067 & & \\
\hline Adjusted $R^{2}$ & 0.20 & & \\
\hline \multicolumn{4}{|l|}{ C. Master's degree } \\
\hline Experience & 532.9 & 23.7 & 22.5 \\
\hline Woman & -11671.3 & 421.2 & -27.7 \\
\hline Black & -1349.4 & 718.7 & -1.9 \\
\hline Hispanic & -3534.4 & 866.9 & -4.1 \\
\hline Asian & -1836.0 & 705.9 & -2.6 \\
\hline Associate's degree & -2117.2 & 537.3 & -3.9 \\
\hline Controls: Major field of study & Yes & & \\
\hline Number of observations & 17,803 & & \\
\hline Adjusted $R^{2}$ & 0.23 & & \\
\hline
\end{tabular}


Table 15, cont'd

Regression Analysis: Effects of Work Experience

\begin{tabular}{|c|c|c|c|}
\hline & Coefficient & Standard error & $t$-Statistic \\
\hline \multicolumn{4}{|l|}{ D. Doctorate } \\
\hline Experience & 1374.1 & 55.5 & 24.8 \\
\hline Woman & -7583.2 & 860.7 & -8.8 \\
\hline Black & -6014.6 & 1791.7 & -3.4 \\
\hline Hispanic & -2556.2 & 1885.4 & -1.4 \\
\hline Asian & -3012.9 & 1086.6 & -2.8 \\
\hline Associate's degree & -6883.8 & 1625.8 & -4.2 \\
\hline Controls: Major field of study & Yes & & \\
\hline Number of observations & 4,521 & & \\
\hline Adjusted $R^{2}$ & 0.25 & & \\
\hline \multicolumn{4}{|l|}{ E. Professional degree } \\
\hline Experience & 1185.5 & 81.5 & 14.6 \\
\hline Woman & -7061.9 & 1340.0 & -5.3 \\
\hline Black & -2025.1 & 2890.2 & -0.7 \\
\hline Hispanic & -2899.1 & 2745.9 & -1.1 \\
\hline Asian & -2455.6 & 2362.8 & -1.0 \\
\hline Associate's degree & -7767.6 & 2392.3 & -3.3 \\
\hline Controls: Major field of study & Yes & & \\
\hline Number of observations & 2,955 & & \\
\hline Adjusted $R^{2}$ & 0.10 & & \\
\hline
\end{tabular}

One might also be concerned that when we compare people of the same age with and without an $\mathrm{AD}$, we in fact compare people with different levels of experience. People who start at a community college take longer, on average, to graduate with a bachelor's degree, so they have less work experience after receiving a bachelor's degree. It could be argued, however, that these people are accumulating work experience while in school if they study part-time and continue to work. Still, to check the robustness of the results, I replaced the age variable in the analysis with the experience variable. "Experience" is defined as the number of years from the time a person received the highest degree until the time of the survey. It is assumed that a person has been working continuously.

The results that control for work experience are presented in Table 15, panels A through E. When work experience is measured more care- fully, the estimated negative effect of having an $\mathrm{AD}$ is somewhat smaller. Overall, people with an AD earn $\$ 2,426$ less per year than people with the same highest degree who have no AD. The earnings gap is smaller for bachelor's and master's degree holders ( $\$ 2,269$ and $\$ 2,117$, respectively) and larger for people with doctorates and professional degrees ( $\$ 6,884$ and $\$ 7,768$, respectively). Note that gender and race effects remain almost unchanged compared with Table 14, panels A through E.

Why does the observed salary gap persist between people with and without a prior $\mathrm{AD}$ even among the highly educated? Data available from the NSCG survey are not sufficient to answer this question. An important caveat of the above analysis is the lack of ability and school performance measures and data on family characteristics, such as family income. One hypothesis is that 
because community college students are more likely to come from families with lower incomes and education, they are also more likely to attend lower-performing elementary and secondary schools. It is possible that they fall far behind even before entering the postsecondary education system. The results seem to suggest that this disadvantage affects educational and labor market outcomes throughout their lives-as a group they never catch up with their peers.

\section{CONCLUSION}

Community colleges play a significant role in U.S. higher education, enrolling 46 percent of current U.S. undergraduates. They offer the opportunity to receive a postsecondary education to many students who would not attend college otherwise: first-generation college students, students from low-income families, and older students who continue to work as they attend classes part-time. Attending a community college even without completing a degree results in economic payoffs-in particular, annual earnings increase by 5 to 8 percent for each year of community college education-and better job opportunities. Today, the number of U.S. undergraduates is at an all-time high as more people understand the necessity of higher education in our technologyintensive world. In addition, historically, college enrollments in general increase during economic downturns. Community colleges are important in helping to absorb this increasing number of students. Currently, community colleges have additional appeal because tuition and fees at four- year colleges continue to increase while financial aid and student loans are harder to obtain.

Despite all the benefits of community colleges, there are downsides as well. The original goal of community colleges was to prepare students to transfer to four-year colleges. Associate's degree programs were intended to accomplish that goal. However, only about 29 percent of community college students transfer to four-year institutions, and only about 16 percent eventually receive a bachelor's degree or higher. Even among those who start their postsecondary education intending to receive a bachelor's degree, only 26 percent accomplish it. They are also much less likely to pursue postgraduate studies.

In addition, the salary gap persists between those with a bachelor's degree or higher and a prior $\mathrm{AD}$ and similar individuals without an $\mathrm{AD}$, even among the highly educated. This gap remains even for people of the same gender, race, education, experience level, field of study, and type of college they attended.

Still, for many students, community colleges offer the best chance to obtain a college education. It is important, however, for individuals to know both the benefits and the disadvantages of attending a community college when making decisions about higher education.

This paper attempts to present a comprehensive overview of how community colleges improve the economic mobility of a significant subset of the U.S. population. A better understanding of all aspects of this complicated subject should be an important priority for researchers and policymakers. 


\section{REFERENCES}

Black, Dan; Kolesnikova, Natalia and Taylor, Lowell. "Earnings Functions When Wages and Prices Vary by Location." Journal of Labor Economics, January 2009, 27(1), pp. 21-47.

Hoachlande, Gary; Sikora, Anna C.; Horn, Laura and Carroll, C. Dennis. "Community College Students: Goals, Academic Preparation, and Outcomes.” NCES Report 2003-164, National Center for Education Statistics, June 2003; http://nces.ed.gov/pubs2003/2003164.pdf.

Horn, Laura and Nevill, Stephanie. "Profile of Undergraduates in U.S. Postsecondary Education Institutions: 2003-04, With a Special Analysis of Community College Students.” NCES Report 2006-184, National Center for Education Statistics, June 2006; http://nces.ed.gov/pubs2006/2006184 rev.pdf.

Jacobson, Louis S.; LaLonde, Robert J. and Sullivan, Daniel G. "Estimating the Returns to Community College Schooling for Displaced Workers." Journal of Econometrics, March/April 2005, 125(1-2), pp. 271-304.

Kane, Thomas J. and Rouse, Cecilia Elena. "Labor Market Returns to Two- and Four-Year College." American Economic Review, June 1995, 85(3), pp. 600-14.

Kane, Thomas J. and Rouse, Cecilia E. "The Community College: Educating Students at the Margin Between College and Work.” Journal of Economic Perspectives, Winter 1999, 13(1), pp. 63-84.

Kolesnikova, Natalia A. and Shimek, Luke. "Community Colleges: Not So Junior Anymore.” Federal Reserve Bank of St. Louis The Regional Economist, October 2008, pp. 6-11;

http://stlouisfed.org/publications/pub assets/pdf/re/2008/d/colleges.pdf.

Kolesnikova, Natalia A. "From Community College to a Bachelor's Degree and Beyond: How Smooth Is the Road?" Federal Reserve Bank of St. Louis The Regional Economist, July 2009a, pp. 10-11;

http://stlouisfed.org/publications/pub assets/pdf/re/2009/c/community college.pdf.

Kolesnikova, Natalia A. “Community Colleges: A Route of Upward Mobility.” Federal Reserve Bank of St. Louis Community Development Research Report, March 2009b, pp. 1-28; http://stlouisfed.org/community development/assets/pdf/CommunityColleges.pdf.

Leigh, Duane E. and Gill, Andrew M. "Labor Market Returns to Community Colleges: Evidence for Returning Adults." Journal of Human Resources, Spring 1997, 32(2), pp. 334-53.

Long, Bridget Terry and Kurlaender, Michal. "Do Community Colleges Provide a Viable Pathway to a Baccalaureate Degree?” NBER Working Paper No. 14367, National Bureau of Economic Research, September 2008; http://papers.nber.org/papers/w14367.pdf.

Rouse, Cecilia E. "Do Two-Year Colleges Increase Overall Educational Attainment? Evidence from the States." Journal of Policy Analysis and Management, Fall 1998, 17(4), pp. 595-620.

Ruggles, Steven; Sobek, Matthew; Alexander, Trent; Fitch, Catherine; Goeken, Ronald; Hall, Patricia; King, Miriam and Ronnander, Chad. "2000 Public Use Micro Sample of the U.S. Census," in Integrated Public Use Microdata Series. Minneapolis, MN: Minnesota Population Center [producer and distributor], 2004;

http://usa.ipums.org/usa/. 


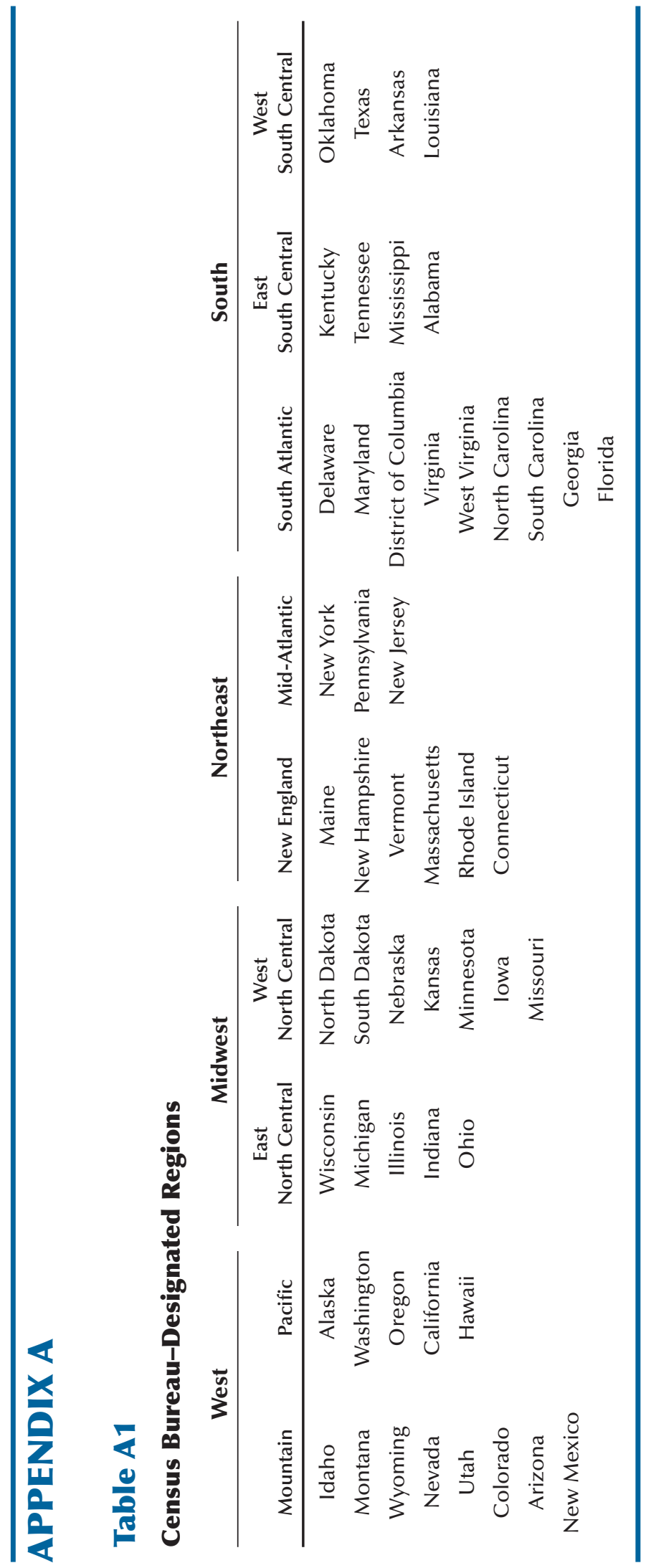




\section{APPENDIX B}

\section{Category Definitions of Carnegie Foundation Classification of Institutions of Higher Education}

The 1994 Carnegie Classification includes all colleges and universities in the United States that are degree-granting and accredited by an agency recognized by the U.S. Secretary of Education.

Research Universities I: These institutions offer a full range of baccalaureate programs, are committed to graduate education through the doctorate, and give high priority to research. They award 50 or more doctoral degrees ${ }^{1}$ each year. In addition, they receive annually $\$ 40$ million or more in federal support. ${ }^{2}$

Research Universities II: These institutions offer a full range of baccalaureate programs, are committed to graduate education through the doctorate, and give high priority to research. They award 50 or more doctoral degrees ${ }^{1}$ each year. In addition, they receive annually between $\$ 15.5$ million and $\$ 40$ million in federal support. ${ }^{2}$

Doctoral Universities I: These institutions offer a full range of baccalaureate programs and are committed to graduate education through the doctorate. They award at least 40 doctoral degrees ${ }^{1}$ annually in five or more disciplines. ${ }^{3}$

Doctoral Universities II: These institutions offer a full range of baccalaureate programs and are committed to graduate education through the doctorate. They award annually at least 10 doctoral degrees-in three or more disciplines-or 20 or more doctoral degrees in one or more disciplines. ${ }^{3}$

Master's (Comprehensive) Universities and Colleges I: These institutions offer a full range of baccalaureate programs and are committed to graduate education through the master's degree. They award 40 or more master's degrees annually in three or more disciplines. ${ }^{3}$

Master's (Comprehensive) Universities and Colleges II: These institutions offer a full range of baccalaureate programs and are committed to graduate education through the master's degree. They award 20 or more master's degrees annually in one or more disciplines. ${ }^{3}$

Baccalaureate (Liberal Arts) Colleges I: These institutions are primarily undergraduate colleges with major emphasis on baccalaureate degree programs. They award 40 percent or more of their baccalaureate degrees in liberal arts fields ${ }^{4}$ and are restrictive in admissions.

Baccalaureate Colleges II: These institutions are primarily undergraduate colleges with major emphasis on baccalaureate degree programs. They award less than 40 percent of their baccalaureate degrees in liberal arts fields ${ }^{4}$ or are less restrictive in admissions.

Associate of Arts Colleges: These institutions offer associate of arts certificate or degree programs and, with few exceptions, offer no baccalaureate degrees. ${ }^{5}$

1 Doctoral degrees include Doctor of Education, Doctor of Juridical Science, Doctor of Public Health, and the Ph.D. in any field.

2 Total federal obligation figures are available from the National Science Foundation's annual report, called Federal Support to Universities, Colleges, and Nonprofit Institutions. The years used in averaging total federal obligations are 1989, 1990, and 1991.

3 Distinct disciplines are determined by the U.S. Department of Education's Classification of Instructional Programs 4-digit series.

4 The liberal arts disciplines include English language and literature, foreign languages, letters, liberal and general studies, life sciences, mathematics, philosophy and religion, physical sciences, psychology, social sciences, the visual and performing arts, area and ethnic studies, and multi- and interdisciplinary studies. The occupational and technical disciplines include agriculture, allied health, architecture, business and management, communications, conservation and natural resources, education, engineering, health sciences, home economics, law and legal studies, library and archival sciences, marketing and distribution, military sciences, protective services, public administration and services, and theology.

5 This group includes community, junior, and technical colleges.

SOURCE: This information is from A Classification of Institutions of Higher Education. Princeton, NJ: The Carnegie Foundation for the Advancement of Teaching Carnegie Foundation, 1994, pp. xix-xxi. Used with permission. 
